\title{
Corporate governance and banks' productivity: evidence from the banking industry in Bangladesh
}

\author{
Md. Harun Ur Rashid ${ }^{1}$ (D) Shah Asadullah Mohd. Zobair ${ }^{1}$ • \\ Md. Asad Iqbal Chowdhury ${ }^{1} \cdot$ Azharul Islam $^{2}$
}

Received: 8 November 2019/Accepted: 9 March 2020/Published online: 26 March 2020

(C) The Author(s) 2020

\begin{abstract}
Though remarkable literature exploring productivity and efficiency has emerged since the last half of the previous century, but dearth studies have been found in showing the impact of corporate governance on banks' productivity. The study aims to investigate the banks' productivity and its relationship with corporate governance. For this purpose, the study examines the productivity of 30 listed banks of Bangladesh deploying a Malmquist Productivity Index (an extension of Data Envelopment Analysis) with a panel data covering the period of five years from 2013 to 2017. The empirical results show that the average productivity of the banks is $1.03 \%$. Finally, the ordinary least square (OLS), fixed effect (FE), and random effect (RE) regression were run separately. The research outcomes show that the productivity of the Bangladeshi banks is significantly influenced by financial performance, ownership structure, and board characteristics. The study provides the researchers, academicians, management of the banks, and regulatory body a new insight of how corporate governance influences the banks' productivity so that they can formulate a better policy to generate more productivity.
\end{abstract}

Md. Harun Ur Rashid

harunais88@gmail.com

Shah Asadullah Mohd. Zobair

sam.zobair@yahoo.com

Md. Asad Iqbal Chowdhury

asad4924@gmail.com

Azharul Islam

azharulru7025@gmail.com

1 Department of Economics \& Banking, International Islamic University Chittagong (IIUC), Kumira, Sitakunda, Chattogram 4318, Bangladesh

2 Department of Business Administration-General, Faculty of Business Studies (FBS), Bangladesh University of Professionals, Mirpur Cantonment, Dhaka 1216, Bangladesh 
Keywords Productivity · MPI · Corporate governance · Banking industry · Bangladesh

\section{Introduction}

To stabilize economic growth, it is necessary to have a strong financial system. The role of the bank as the intermediary is inevitable to stabilize the economy, as the banks play a crucial role by providing the fund to the borrowers (Diamond and Rajan 2005). Banks also facilitate the economy to reduce the unemployment problem and improve GDP by providing capital investment to large industries (Arif and Nauman Anees 2012).

In recent years, the banking industry is facing increased competition to improve its services, forced by technological changes and deregulations. As consequent of the increasing focus in the banking arena, the emphasis has been given on the improvement of the efficiency of the banking industry (Fiordelisi et al. 2011). As an output of this process, banks are forced to operate near to the "best-practice" or efficient at its service providing. The banking industry's smoothness makes the economy more productive and also viable to manage any external and negative shocks (Athanasoglou et al. 2006). Moreover, due to the liberalization of the economy and monetary policy, foreign banks are also entering into the local markets, affecting the local banks' monopoly power, resulting in lower profitability and productivity (Mirzaei et al. 2013).

Presently, two kinds of banks are operating in the economy of Bangladesh, scheduled banks (operated under the Bangladesh Bank order-1972) and nonscheduled banks (operated for the particular purpose under the special act). The number of scheduled banks is 59, which include nationalized, private, and foreign commercial banks. Some of the private commercial banks run their banking according to Shari'ah. The emergence of the National Commission on Money, Banking, and Credit in the year 1986 put first priority on efficiency and soundness of the banking sector of Bangladesh (Sufian and Kamarudin 2013). In 1991, World Bank expanded its assistance to Bangladesh Bank, ${ }^{1}$ to enhance the supervision, monitoring, and regulation of the banking sector (Sufian and Kamarudin 2013). For the smooth operation of the banking system, it is required to ensure operational efficiency in the banking industry. Researchers started to re-evaluate the banking sector's efficiency due to the crisis in the transition and advancement in the economy and banking structure (Honohan and Klingebiel 2003).

This study uses Malmquist Total Factor Productivity Index (MPI) to identify the productivity of the banking sector in Bangladesh. The MPI is a commonly used technique for assessing a financial institution's productivity adjustment due to its benefits. It utilizes a non-parametric method equivalent to DEA rather than an econometric estimate. Sten Malmquist first proposed MPI in 1953 and many scientists evolved it (Malmquist 1953). The MPI was focused on the production

\footnotetext{
1 The central bank of Bangladesh.
} 
function idea, which was dependent on a set of inputs as a function of maximum feasible production.

Earlier researchers put their concentration on the banks' efficiency in advanced economies (Girardone et al. 2004; Henriques et al. 2018; Pervez et al. 2018). However, recently, some of the researchers are focusing on the efficiency of the banking system in the developing countries (Banna et al. 2017; Parinduri and Riyanto 2014; Tamatam et al. 2019). Research on ASEAN countries suggested that banks operating in the Philippine are suffering from cost-efficiency (Ferrier 2001). Girardone et al. (2004) identified that the unfavorable outcome of the post-crisis reformation of the banking industry, which made the local banks inefficient. During the period of the global financial crisis, ASEAN countries also affected and Thai banks faced inefficiencies (Sufian and Shah Habibullah 2010). Only a few studies were conducted on the efficiency of the Bangladeshi banks (Hoque and Rayhan 2013; Sufian and Kamarudin 2013). These earlier studies focused on measuring only the efficiency of the banks and not concentrated on the banks' productivity and its determinant as well.

Researchers now recognize corporate governance as one of the fundamental principles to ensure the banks' efficiency. To boost operational efficiency, it is essential to implement successful corporate governance by ensuring risk minimization, creating value, and improving public accountability (Fu et al. 2014). Investors, authorities and banks show their interest in identifying how determinations to maintain good governance of corporations lead their companies to improve output. Banks aim to provide greater management oversight of their corporate governance structures, authorities or regulators are looking for fewer failures and greater stability, and investors or owners always seek the value of their money (Adams and Mehran 2012). However, recent researchers have shown their interest in including corporate governance to analyze bank performance (Adams and Mehran 2012; Shehzad and De Haan 2015).

Bank productivity and efficiency-related studies have grown significantly over the last 30 years. For example, García-Alcober et al. (2019) explored the productivity of the Spanish banks where the more inefficient bank takes a higher risk during the period of choosing borrowers, imposing interests and taking the collateral. As per the study of Epure et al. (2011), productivity is decomposed into technological and efficiency change using the Malmquist Productivity Index (MPI). Alexakis et al. (2019) also adopted MPI to conduct a comparative investigation of productivity and operational outcomes of conventional banks and Shari'ah based banks. To investigate the impact of corporate governance on the banks' efficiency, Romano et al. (2012a, b) also used the similar method.

Some remarkable studies focused on some financial indicators such as ROA, ROE, and Tobin's Q to explore the impact of corporate governance and financial performance. For instance, Al-ahdal et al. (2020) focused on the listed banks of India and GCC and examined the relationship between corporate governance and financial performance. Hoque et al. (2013) evidenced that the firms' size along with the board and ownership structure influence the financial output of the banks. Ciftci et al. (2019) and Romano et al. (2012a, b) also explored the role of governance in organizational performance. However, no study has been found to investigate the 
relationship between corporate governance and banks' productivity which is identified as a significant gap in the existing literature.

Furthermore, though the volume of research works has been done to quantify the efficiency and effectiveness of the banking industry in Bangladesh, no study has been found to consider corporate governance as the determinant of productivity of the banks. Moreover, research on the impact of the ownership structure (in terms of shareholding positions) on the productivity of the banks has not yet conducted. To fill this gap, this study aims at finding the impact of corporate governance on the Bangladeshi banks' productivity. Successful accomplishment of this aim would facilitate the following insights. First, it provides an idea about how the pattern of Bangladeshi banks' ownership structure affects productivity. Second, it investigates the productivity of the banks using the MPI of DEA. Finally, it measures how corporate governance affects the productivity of banks.

The remaining parts of the paper are structured as follows: literature review and theoretical background would be explored first. Then, the methodology of this research has been addressed. Following the methodology, the outcomes of the empirical analysis have been discussed. In the final section, implication, conclusion, and directions for further studies have been presented.

\section{Theory and hypotheses development}

Earlier studies related to corporate governance indicate the intricacies of the company's multifaceted nature and behavior. As no theoretical viewpoint can completely encompass the complexities of an institute (Cullen et al. 2006), it requires various theories from a different perspective to provide a better explanation for the attributes of corporate governance (Hoque et al. 2013). Since the firm performance is profoundly affected by the relationship of various stockholders such as shareholders, employees, and the communities (Hill and Jones 1992), the banks' productivity is highly related to stakeholder theory. The theory claims the importance of the board of directors and stockholders to decide the desired paths of the organization. Proper management of such a relationship is the key to organizational success. In the pave of success, the significance of corporate governance is immense. It has been argued that the key fuel behind such a relationship is trust. Alternatively, the theory of resource dependency provides information about a company's responsibility to contribute benefits to the companies both internally and externally (Preffer and Salancik 1978). Liu et al. (2012) reported that while the agency and resource-based viewpoints have dominated family business literature, organizations affect how and where ownership predominates and how the output is affected. Cullen et al. (2006) indicated that the agency stewardship theories focus on the achievement of firms' goals. The agency theory also emphasizes on conflicting principles and interest of agents at the firm level. The philosophy of stewardship seeks to balance commitment between the steward and the objectives of an organization. Additionally, another prime focus of agency theory is to investigate the difficulties that are likely to derive due to parting of control from ownership. Such investigation facilitates the desired way of 
outlining the relationships in which all the parties' interests could be balanced through a monitoring scheme (Hoque et al. 2013). The theoretical basis of this article also includes the theory of agencies based on the study of Jensen and Meckling (1976), which opened up the significant region on the separation of ownership and control within the contemporary company. Active corporate governance mechanisms, according to agency theory, provide better align executives' and shareholders' interests, which consequently improve company efficiency and productivity.

Previous studies relating to the association between corporate governance and organization's performance included board diversification, ownership structure, and features of the audit committee. The measurement of banks' productivity depends on accounting and market measure. To address the issue of the relationship between corporate governance and firms' productivity, the study considers the ownership structure and board composition based on the existing literature.

Ownership structure demonstrates that shareholder concentration from the perspective of both in-house and outside plays a dominating role in ensuring the efficiency of corporate governance. Some instances are found that dictate a high level of control of larger shareholders may result in some deviations in the cash flow-controlling process (Hoque et al. 2013). Such deviation may facilitate such dominating shareholders to confiscate assets by dint of private advantage at the cost of minor shareholders. Empirical findings are vague concerning the concentration of ownership and corporate performance. Bangladeshi banks are owned by the board of directors, foreigners, institutions, government, and publics. While examining relationships, the research explores the efficacy of the governance characteristics on productivity by considering directors, foreign, and institutional ownership.

\subsection{Foreign ownership}

Foreign owners and investors may have pressure on the board to cope with best practices from abroad (Brewster et al. 2008). As they contribute a large amount of capital with knowledge and experience, they incline to promote better performance (Ciftci et al. 2019). Thus, this study is also aware of the crucial impact derived from foreign ownership of Bangladeshi bank and subsequently produces the following hypothesis:

H1 Foreign ownership has a positive impact on TFP.

\subsection{Directors' ownership}

Board of directors (BoD) consists of members from multiple sources who are responsible for overseeing and protecting the interest of all shareholders. Some members of the board hold a certain percentage of shares of a limited company, though it is not mandatory for all the board members to hold the ownership of the firm. A systemic trend consistent with an optimal contracting equilibrium in the managerial ownership is identified and their monitoring activities are anticipated to provide the shareholders a higher value (Chen et al. 2008). More specifically, the 
director always attempts to capture the shareholders' benefits with their controlling power. When the directors find that the assets held by them in more risk and possibility of loss, they can abuse their discretion more easily (Chen et al. 2008). On the contrary, when they find themselves as both owners and managers, it is easy for them to manage funds of the institutions and get more flexibility to take actions against the interests of shareholders. Based on the discussion, the study posits the following hypothesis:

H2 Directors' ownership has a positive impact on TFP.

\subsection{Institutional ownership}

The percentage of institutional owners is $8-9$ in the ownership structure in the Bangladeshi banking industry; it has become relevant due to the enhanced investment in stocks and their role in corporate governance characteristics (Hoque et al. 2013). Shleifer and Vishny (1997) argued that institutional ownership could improve the firms' performance by reducing the agency cost and managerial opportunism and expropriation of minorities. Ho (2005) indicated that substantial holdings by institutional investors increase the boards' vigilance, which results in a positive impact on firm performance, while Dhnadirek and Tang (2003) found no significant connection between institutional ownership and firm performance. Thus, this research produces the following hypothesis:

H3 Institutional ownership has a positive impact on TFP.

\subsection{Board size}

As top executives' body of a company, the board of directors is assigned with the responsibility to formulate strategies and policies and to supervise the company's operation. It is a dilemma to fix up the optimal number of board members as Bangladesh Bank proclaims that "the board of directors of the bankcompanies shall be constituted of maximum 13 (thirteen) directors". The proverb "too many cooks spoil the broth" may be correct to have many members of the board, while decision-making accuracy may be hindered by being too few members. Both positive and negative relationship between board size and firm efficiency were observed in the previous studies. Hoque et al. (2013) found a significant and positive association with ROA and board size, while there was no relationship with ROE and Tobin's Q. Moreover, the study of Ciftci et al. (2019) also claimed a positive and noteworthy association between board size and firm performance, while the study of Romano et al. (2012a, b) dictated that operational and financial performance of firms do not depend on board size. Nevertheless, some other researchers have included the board size in their research as it affects the extent to which a company monitors, controls, and makes decisions (Haniffa and Hudaib 2006). Since the mixed outcomes are found regarding the impact of board size on the firms' performance, this study focuses significantly on exploring the dominance of board size on 
the performance of the Bangladeshi banks. Therefore, the study posits the following hypothesis.

H4 Board size has a positive impact on TFP.

\subsection{Independent board member}

Following recent corporate scandals, policymakers and regulatory bodies around the world focused on the higher magnitude of boards' independence from top corporate management (Dalton and Dalton 2005). An independent board member has fewer potential conflicts of interest in supervisory executives, although the existence of external directors entails extra expenses for the company (Romano et al. 2012a, b). In this sense, the monitoring efficiency should be increased by the independent directors as they represent only shareholders' interests, not the interest of employees. Referring to Italy, Romano et al. (2012a, b) also found that economic fraud risk is likely to be reduced due to the greater part of independent directors on the board, since the independent director is more effective to imply organizational control. Therefore, they can play an important role in the better productivity of the banks. Consequently, the study proposes the following hypothesis:

H5 Independent board member has a positive impact on TFP.

\subsection{Accounting experts on the board}

The function of the board's accounting specialists (AE) is to supervise the accounting process and systems, ensure transparency in financial reporting, and maintain accountability of financial data and records and protect the company's internal control (Kassinis and Vafeas 2002). Accounting plays a crucial role in keeping the organization on track. If the board of directors includes an expert in accounting, then the internal control system could be supervised effectively. As an accounting and auditing specialist, a board accountant also helps to monitor the ability of the management to make economic choices and offers experience-based views on the control of the financial statements of the firm (Klein 2002). Furthermore, the study of Kusnadi et al. (2016) outlined the evidence from Singaporean firms that accounting specialists on the board encourage the quality of financial reporting substantially. They further confirmed these outcomes by considering both accounting and economic specialists and reporting the same outcomes, noting that accounting specialists act as a watchdog on the company's financial reporting system (Kusnadi et al. 2016; Masud et al. 2019). Accounting experts of a firm always concentrate on the profitability of a firm rather than the sustainability of that firm. Accounting experts always try to maximize the profit of a firm. No previous research has recorded an accounting expert's role in Bangladeshi companies ' productivity, leading us to state the following assumption:

H6 Accounting experts on the board have a positive impact on TFP. 


\subsection{Legal experts on the board}

Having legal experts (LE) on the board allows companies to obtain adequate guidance, suggestions, recommendations, and guidance on financial and nonmonetary agreements with the third entities, how to handle legal problems within the institutions and how to grip accusations of corruption (Masud et al. 2019). Lawyers are regarded to be extremely skilled, professional individuals whose legal background allows them to cope efficiently with delicate political, social, and environmental performance (De Villiers et al. 2011). Furthermore, having a legal expert among the board members augments the legal power of the board regarding financial decision-making. The activities of the lawyers also help in controlling and preventing the firms' external pressure and internal corruption and guard the interests of the shareholders, which in turn enhances the productivity of the firms. No studies have been found to show the relationship between LE and productivity, it motivates the authors to investigate the relationship. The study posits a significant and positive relationship between LE and productivity.

H7 Legal experts on the board have a positive impact on TFP.

\section{Methodologies}

A two-step analysis would be followed in this study. In the first step, MPI theory would be used to assess total factor productivity (TFP) which would be followed by multiple regression analysis later. Initially, TFP of 30 listed Bangladeshi banks is assessed. Then, a regression is conducted to explain how ownership structures and board characteristics with the presence of some controlled variables impact the banks' productivity. The MPI, multiple regression model with bank productivity determinants, sampling, and sourcing of data is precisely explained below:

\subsection{Estimating productivity: the Malmquist Productivity Index (MPI)}

MPI is being considered as a sensible productivity measurement tool in the banking industry irrespective of formal or informal intuitions (Mia and Soltane 2016). This index focuses on assessing change in the productivity of a particular unit between two subsequent points of time (Daskovska et al. 2010). MPI is recognized superior to other methods, since it does not require prices of input and output and it is independent of behavioral assumptions such as assumption of cost or profitability (Daskovska et al. 2010). Along with these, MPI permits index decomposition that helps search for factors that cause changes in productivity (Grifell-Tatje and Lovell 1996). The TFP is decomposed into two branches, such as Technical Efficiency Change (TEC) and Technological Change (TC) (Mia and Soltane 2016). TEC dictates the efficiency level of decision-making units (DMU); where efficiency dictates generating a particular level of output using a minimal level of inputs. Conversely, TC infers the involvement of superior technology and the latest equipment with a production process that ensures the optimal combination of 
outputs and inputs (Chandran and Pandiyan 2008). The geometric mean of two technology-based indices for two successive points of time indicates TFP's Malmquist Index (M) (Matthews and Zhang 2010).

This study would focus on output-oriented MPI. Färe et al. (1994) suggested the following formula for defining output-oriented MPI for two consecutive periods, i.e., $t$ and $t+1$. Between time $t$ and $t+1$, an MPI value greater than 1 indicates a positive change in TFP, and accordingly, negative change is indicated an MPI's value less than 1 (Matthews and Zhang 2010):

$$
\begin{gathered}
M_{0}\left(Y^{t+1}, X^{t+1}, Y^{t}, X^{t}+\left[\frac{d_{0}^{t}\left(X^{t+1}, Y^{t+1}\right)}{d_{0}^{t}\left(X^{t}, Y^{t}\right)} \times \frac{d_{0}^{t+1}\left(X^{t+1}, Y^{t+1}\right)}{d_{0}^{t+1}\left(X^{t}, Y^{t}\right)}\right]^{2}\right. \\
M_{0}=\left[\frac{d_{0}^{t}\left(X^{t+1}, Y^{t+1}\right)}{d_{0}^{t+1}\left(X^{t}, Y^{t}\right)}\right] \times\left[\frac{d_{0}^{t}\left(X^{t+1}, Y^{t+1}\right)}{d_{0}^{t}\left(X^{t}, Y^{t}\right)} \times \frac{d_{0}^{t+1}\left(X^{t+1}, Y^{t+1}\right)}{d_{0}^{t+1}\left(X^{t}, Y^{t}\right)}\right]^{2} \\
M_{0}=\operatorname{TEC}\left(Y^{t+1}, X^{t+1} Y^{t} X^{t}\right) \times \operatorname{TC}\left(Y^{t+1}, X^{t+1} Y^{t} X^{t}\right) .
\end{gathered}
$$

TEC could be divided into two parts named as Pure Technical Efficiency change (PTE) and Scale Efficiency (SE). Färe et al. (1994) also suggested the following definitions in this regard:

$$
\mathrm{TEC}=\frac{D_{\mathrm{VRS}}^{t+1}\left(X^{t+1}, Y^{t+1}\right)}{D_{\mathrm{VRS}}^{t}\left(X^{t}, Y^{t}\right)} \times\left[\frac{D_{\mathrm{CRS}}^{t+1}\left(X^{t+1}, Y^{t+1}\right) / D_{\mathrm{VRS}}^{t+1}\left(X^{t+1}, Y^{t+1}\right)}{D_{\mathrm{CRS}}^{t}\left(X^{t}, Y^{t}\right) / D_{\mathrm{VRS}}^{t}\left(X^{t}, Y^{t}\right)}\right] .
$$

Here, output distance function is explained from two perspectives such as $D_{\mathrm{CRS}}$ and $D_{\mathrm{VRS}} ; D_{\mathrm{CRS}}$ is the output function for constant return to scale; and $D_{\mathrm{VRS}}$ is the output function for variable return to scale (Mia and Soltane 2016). The first part of the equation of TEC indicates PTE, it is followed by SE in the second part. The DMU's ability to use inputs to have maximum outputs by minimizing wastage is dictated as PTE; alternatively, SE is defined as the capacity of working at an optimal magnitude (Bassem 2014). Additionally, SE is a measurement that indicates the extent by which productive efficiency could be enhanced by focusing on reaching technically optimal productive scale (Emrouznejad and Cabanda 2014).

The approach used for this study combines VRS with an output-oriented model in estimating MPI. Prior studies also used this approach over other approaches such as output-oriented CRS, input-oriented CRS and input-oriented VRS for some significant characteristics such as greater outreach, added synergies, and superior implications in imperfect economic condition (Basharat et al. 2015; Mia and Soltane 2016). Moreover, VRS is such a frontier scale in DEA that supports measuring the efficiency of an increase or decrease in input or output (Cooper et al. 2011). VAR exhibits increasing and decreasing returns to scale, while CRS shows only the constant returns to scale while working in DEAP. Therefore, the study used the VRS output-oriented model over the CRS.

\subsection{Modeling determinants of bank productivity}

Many disputes are common in deciding the right model to be used in the second stage. The use of OLS or Tobit regression has been criticized by Simar and Wilson 
(2011) due to challenges to be faced by a bounded score of DEA between 0 to 1 , and alternatively, a truncated bootstrapped approach is recommended for the secondstage regression analysis. Conversely, some researchers, for instance, Banker and Natarajan (2008) and McDonald (2009), claimed more consistent estimation by OLS in the second stage. More recently, Banker et al. (2019) signified the use of the DEA + OLS model to outstrip the more intricate DEA + bootstrapped truncated model. The two-step analysis that has been used in this research is also used in some contemporary studies; for instance, Sufian (2011) used to analyze banking sector productivity, and Mia and Soltane (2016) and Wijesiri and Meoli (2015) used for the productivity of microfinance institutions. The functional form of the relationship between corporate governance and banks' productivity is specified as follows:

$$
\begin{aligned}
\mathrm{TFP}_{i t}= & \alpha_{0}+\beta_{1} \mathrm{SIZE}_{i t}+\beta_{2} \mathrm{AGE}_{i t}+\beta_{3} \mathrm{NP}_{i t}+\beta_{4} \mathrm{ROE}_{i t}+\beta_{5} \mathrm{FS}_{i t}+\beta_{6} \mathrm{IS}_{i t}+\beta_{7} \mathrm{DS}_{i t} \\
& +\beta_{8} \mathrm{BOARD}_{i t}+\beta_{9} \mathrm{IBM}_{i t}+\beta_{10} \mathrm{LE}_{i t}+\beta_{11} \mathrm{AE}_{i t}+\varepsilon_{i t} .
\end{aligned}
$$

The variables are defined in Appendix 1. Here, ' $i$ ' and ' $t$ ' indicates the number of banks and time period respectively. $\beta_{1}$ to $\beta_{4}$ are the coefficients of control variables, while $\beta_{5}$ to $\beta_{7}$ are the coefficients of ownership structures, and $\beta_{8}$ to $\beta_{11}$ are the coefficients of board characteristics. Moreover, $\alpha_{0}$ is the constant and error term $\varepsilon_{i t}$ indicates error within entities. To enhance the goodness of fit of the model and trounce simultaneity bias, a natural logarithm is used for some variables (De Bandt and Davis 2000), and in the regression model, the use of log transformation facilitates a better interpretation of findings (Mia and Soltane 2016).

\subsection{Sampling and data source}

For this research, balanced panel data of all 30 listed banks of Bangladesh have been used. Though very recent data with a longer period would have been better for such a study (Nartey et al. 2019), but the study uses data for the period of 2013 to 2017 due to some accessibility problems. All inputs and outputs data used in DEA analysis, as well as the data of determinants of productivity used in regression analysis, are collected from annual reports of respective banks.

\section{Results and discussion}

\subsection{Descriptive analysis}

Table 1 presents the descriptive statistics of all 30 listed banks covering the period 2013-2017. The analysis reveals that there is a huge fluctuation in the ROE among the banks in Bangladesh with a range of -7.62-22.16. Like the profitability measure, ROE, the assets which are used as a proxy to the size of the banks also show highly fluctuating in the industry. The percentage of shareholding by foreign shareholders, institutional shareholders, and directors represent a flexible capital structure of the banks in Bangladesh. A higher percentage of domestic shareholding 
Table 1 Descriptive statistics

\begin{tabular}{lllrll}
\hline Variables & Observations & Mean & SD & Minimum & Maximum \\
\hline Interest expense (INE) BDT & 150 & 11014.06 & 5238.52 & 380.32 & 31383.09 \\
Non-interest expense (NONINEX) & 150 & 4708.37 & 2715.95 & 455.39 & 18751.44 \\
$\quad$ BDT & 150 & 177748.6 & 102315.4 & 10893.98 & 755022.3 \\
Deposit (D) BDT & 150 & 15938.55 & 8151.62 & 392.61 & 57141.63 \\
Interest income (ININ) BDT & 150 & 2655.88 & 1891.69 & 84.43 & 8981.1 \\
Non-interest income (NOININ) BDT & 150 & 151992 & 92380.33 & 8834.49 & 710728.9 \\
Loan (L) BDT & 120 & 1.035 & 0.14 & 0.76 & 2.36 \\
Total factor productivity (TFP) & 120 & 12.23 & 0.64 & 9.37 & 13.71 \\
Log form of assets (SIZE) & 120 & 24.51 & 9.5 & 13 & 45 \\
Age of banks (AGE) year & 120 & 8.58 & 0.51 & 7.46 & 9.73 \\
Log form of net profit (NP) & 120 & 11.04 & 5.22 & -7.62 & 22.16 \\
Return on equity (ROE) \% & 120 & 5.47 & 14.09 & 0 & 58.46 \\
Foreign share (FS)\% & 120 & 33.24 & 16.33 & 0 & 62.33 \\
Director share (DS)\% & 120 & 18.61 & 11.35 & 0 & 57.06 \\
Institutional share (IS)\% & 120 & 13.78 & 3.79 & 7 & 21 \\
Board member (BOARD) & 120 & 2.59 & 1.03 & 1 & 8 \\
Independent Board Member (IBM) & 120 & 0.89 & 1.08 & 0 & 5 \\
Accounting experts (AE) & 120 & 0.59 & 0.79 & 0 & 3 \\
Legal experst (LE) & & & & & \\
\hline
\end{tabular}

increases the agency cost, whereas the involvement of institutional shareholders in the capital structure can reduce the cost of agency and improve a firm's performance by reducing managerial opportunism (Shleifer and Vishny 1997). The board comprises both executive and non-executive directors, but the proportion of independent directors is deficient as compared to the total number of directors on the board as the mean value of independent directors is 2.59 , whereas the mean value for total directors on the board is 13.78. Therefore, the strategic decisions are dominated by the executive directors in the banking industry of Bangladesh (Reaz and Arun 2006). The Bangladeshi banks, as the insurer of the money deposited by the depositors, maintain a consistent audit committee having five members on average to ensure effective accountability and transparency in the recording process of the firms (Reaz and Arun 2006). Again, interest income, a significant output variable, is considered as the primary source of revenue of the sector, and it has a much lower contribution than the non-interest income in the total income of the banks. It indicates a lack of productivity in the ordinary activity of the sector. Finally, the average deposit (177748.6) which is relatively higher than the average loan (151992) provided by the bank, and this is because of maintaining a certain percentage of deposits as CRR and SLR as per the guideline of the central bank. 


\subsection{The productivity of the banks}

This study uses the MPI as an extension of DEA developed by Sten Malmquist (1953) to estimate the productivity score of each bank and the productivity of the sector using three input and three output variables. Appendix 2 represents the productivity of all listed banks for four year period covering from 2013-2014 to 2016-2017 along with the average productivity of the period and the average productivity of each decision-making unit (DMU). However, the average annual productivity of the Bangladeshi banking industry is $1.03 \%$.

Investigating the productivity by individual banks of Bangladesh, it reveals that highest productivity $(1.342 \%)$ is achieved by the Al-Arafa Islami Bank Ltd. (AIBL), whereas the lowest average productivity is for Exim Bank Ltd. during the sample period. Only the two banks, AIBL and Dutch Bangla Bank Ltd. (DBBL) are experiencing average productivity increase by more than $10 \%$ during the study period. The Islami Bank Bangladesh Ltd. is one of the leading Islami banks in Bangladesh, whose productivity increase is very close to ten (9.2\%). AIBL has the highest average productivity score with greater fluctuation ranging from the score of 0.998 in 2014-2015 to 2.36 in 2016-2017, which indicates weak sustainability in its productivity. Although the average productivity of the DBBL is much lower than the productivity of AIBL, it has higher sustainable productivity only within the range of the score of 1.052 to 1.221 . Among the less productive commercial banks, the First Security Islami Bank Ltd. and Exim Bank Ltd are experiencing negative productivity for the entire period of the study. Among the entire four years of study, the sector has almost similar productivity for the first three years. However, there is a greater increase in the productivity of the banking sector in the financial year 2016-2017 with an average productivity score of 1.101 . This result indicates that the productivity of the Bangladeshi banks is increasing day by day.

\subsection{Correlation}

This study is based on panel data which needs some pre-tests investigation to run. Such pre-tests are required to confirm whether they fit for the model. One such test is the multicollinearity test. Multicollinearity is a test to determine whether the independent variables are correlated or not. Having a high-level presence of multicollinearity indicates a collinearity problem in the data set. Such a collinearity problem may affect the model and lead the $p$ value to be misinterpreted. To test the multicollinearity first, we estimate the Pearson pair-wise correlation between the independent variables. The findings of the test presented in Table 2 show that there is no high degree of correlation among the independent variables. None of the correlation coefficients exceeds the acceptable value of 0.8 for a further statistical test (Farrar and Glauber 1967). Furthermore, the variance inflation factor (VIF) was conducted to ensure more whether the collinearity exists in the model presented in Table 3. The results show all the values below the threshold of 10 (Hair et al. 1984), it proves again that the study is free from multicollinearity issue. 


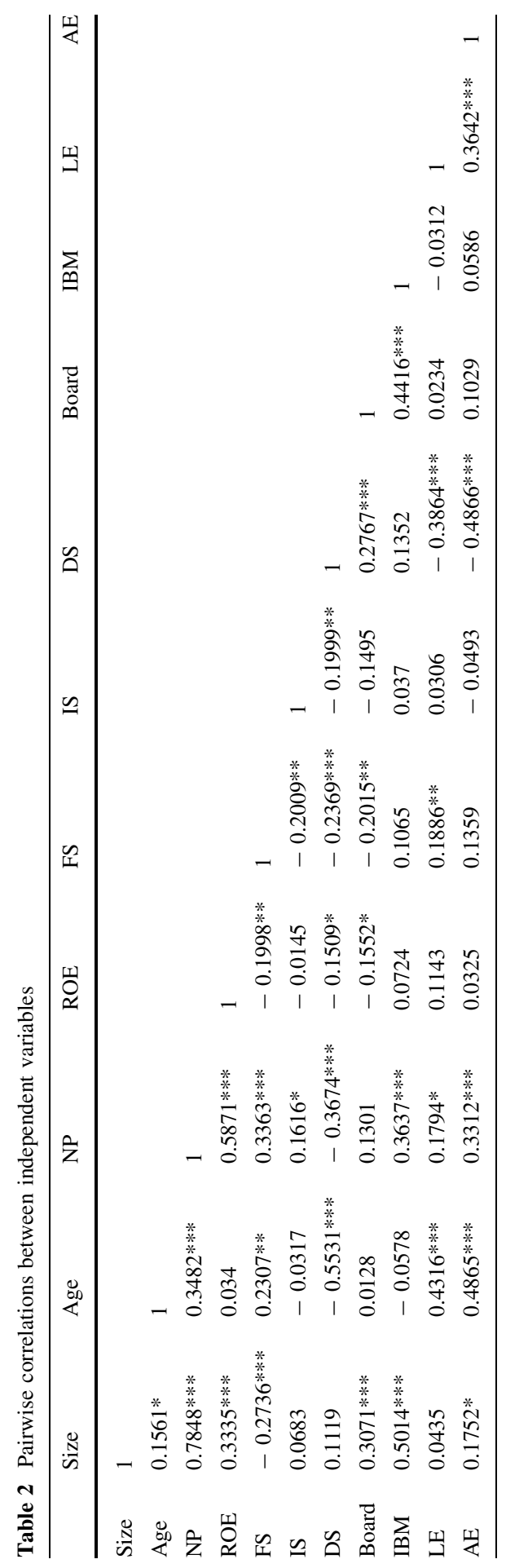


Table 3 Collinearity test

\begin{tabular}{lll}
\hline Variable & VIF & $1 / \mathrm{VIF}$ \\
\hline NP & 5.25 & 0.19063 \\
Size & 4.29 & 0.23331 \\
ROE & 2.56 & 0.39049 \\
AGE & 2.3 & 0.43426 \\
DS & 2.23 & 0.44807 \\
AE & 2.16 & 0.46216 \\
FS & 2.1 & 0.47678 \\
IBM & 1.83 & 0.54505 \\
BOARD & 1.68 & 0.5936 \\
IS & 1.45 & 0.68934 \\
LE & 1.41 & 0.71078 \\
Mean VIF & 2.48 & \\
\hline
\end{tabular}

\subsection{Regression results}

Following the objectives of the study, we run our regression model presented in Table 4, which included all factors relating to financial performance, ownership structure, and board characteristics of the banks. We applied the ordinary leastsquares model (OLS) and the generalized model of the least-squares approach of random and fixed effect. The estimation of the three models provided mixed results.

Among the capital structure components of the banks, the foreign and domestic shareholders positively influence the bank's productivity. The research result regarding the positive impact of foreign and domestic ownership on bank productivity is statistically significant under both fixed effect and OLS model at a $1 \%$ level. The random effect model shows a slight degree of the negative impact of domestic shareholders on the bank's productivity, but the result is statistically insignificant. Our results are expectedly consistent with the previous studies (Brewster et al. 2008; Chen et al. 2008; Ciftci et al. 2019). A significant, as well as a positive relationship between bank's productivity and ownership of directors and foreign investors in both the OLS and fixed-effect model, is consistent with the findings of Ciftci et al. (2019). The regulatory authorities are suggested to increase the number of foreign and directors' shareholders to have better productivity of the firm. Since foreigners have diversified knowledge, it makes their firm more productive. Similarly, the director owners have an opportunity to monitor their selfinterests as a shareholder; they always try to enhance their firms' productivity.

The impact of institutional shareholding on bank's productivity is found insignificant as per OLS and fixed-effect model. Interestingly, a significant relationship between productivity and institutional ownership is shown by the random effect model at the $10 \%$ level. However, the null hypothesis is rejected by the Hausman test, as the test shows the $p$ value of 0.03 , which is less than 0.05 . Therefore, the finding suggests that the factors of corporate governance used in the study have a fixed effect on productivity rather than random effect. This result is 
Table 4 Regression results (OLS, random, and fixed effect) on the determinants of productivity

\begin{tabular}{|c|c|c|c|c|c|}
\hline & $\begin{array}{l}\text { (1) } \\
\text { Expected sign }\end{array}$ & $\begin{array}{l}(2) \\
\text { OLS }\end{array}$ & $\begin{array}{l}\text { (3) } \\
\text { Random effect }\end{array}$ & $\begin{array}{l}\text { (4) } \\
\text { Fixed effect }\end{array}$ & $\begin{array}{l}\text { (5) } \\
\text { Remarks }\end{array}$ \\
\hline Size & & $\begin{array}{l}-0.0133 \\
(0.0318)\end{array}$ & $\begin{array}{l}-0.2469^{*} \\
(0.1261)\end{array}$ & $\begin{array}{l}-0.0133 \\
(0.0318)\end{array}$ & \\
\hline AGE & & $\begin{array}{l}0.0470 * * \\
(0.0234)\end{array}$ & $\begin{array}{l}0.9023 * * * \\
(0.3299)\end{array}$ & $\begin{array}{l}0.0470^{* *} \\
(0.0234)\end{array}$ & \\
\hline NP & & $\begin{array}{l}0.0166 \\
(0.0261)\end{array}$ & $\begin{array}{l}0.0284 \\
(0.0959)\end{array}$ & $\begin{array}{l}0.0166 \\
(0.0261)\end{array}$ & \\
\hline ROE & & $\begin{array}{l}0.0021^{* * * *} \\
(0.0008)\end{array}$ & $\begin{array}{l}0.0027 \\
(0.0023)\end{array}$ & $\begin{array}{l}0.0021^{* * * *} \\
(0.0008)\end{array}$ & \\
\hline FS & + & $\begin{array}{l}0.0020^{* * * *} \\
(0.0008)\end{array}$ & $\begin{array}{l}0.0016 \\
(0.0015)\end{array}$ & $\begin{array}{l}0.0020^{* * * *} \\
(0.0008)\end{array}$ & Supported \\
\hline IS & + & $\begin{array}{l}0.0006 \\
(0.0006)\end{array}$ & $\begin{array}{l}0.0019 * \\
(0.0011)\end{array}$ & $\begin{array}{l}0.0006 \\
(0.0006)\end{array}$ & Not supported \\
\hline DS & + & $\begin{array}{l}0.0014 * * * \\
(0.0005)\end{array}$ & $\begin{array}{l}-0.0007 \\
(0.0018)\end{array}$ & $\begin{array}{l}0.0014 * * * \\
(0.0005)\end{array}$ & Supported \\
\hline BOARD & + & $\begin{array}{l}-0.0029 \\
(0.0021)\end{array}$ & $\begin{array}{l}0.0033 \\
(0.0077)\end{array}$ & $\begin{array}{l}-0.0029 \\
(0.0021)\end{array}$ & Not supported \\
\hline LE & + & $\begin{array}{l}0.0217 * * \\
(0.0085)\end{array}$ & $\begin{array}{l}0.0447 * \\
(0.0233)\end{array}$ & $\begin{array}{l}0.0217 * * \\
(0.0085)\end{array}$ & Supported \\
\hline $\mathrm{AE}$ & + & $\begin{array}{l}-0.0076 \\
(0.0083)\end{array}$ & $\begin{array}{l}-0.0466^{* *} \\
(0.0231)\end{array}$ & $\begin{array}{l}-0.0076 \\
(0.0083)\end{array}$ & Not supported \\
\hline IBM & + & $\begin{array}{l}-0.0042 \\
(0.0083)\end{array}$ & $\begin{array}{l}-0.0119 \\
(0.0184)\end{array}$ & $\begin{array}{l}-0.0042 \\
(0.0083)\end{array}$ & Not supported \\
\hline _CONS & & $\begin{array}{l}0.8064 * * * \\
(0.2650)\end{array}$ & $\begin{array}{l}0.8954 \\
(0.5916)\end{array}$ & $\begin{array}{l}0.8064 * * * \\
(0.2650)\end{array}$ & \\
\hline$N$ & & 120 & 120 & 120 & \\
\hline $\mathrm{F}$ & & 4.4053 & 3.5956 & & \\
\hline$r^{2}$ & & 0.3264 & 0.3514 & & \\
\hline$r_{\mathrm{a}}^{2}$ & & 0.2523 & 0.0138 & & \\
\hline
\end{tabular}

Standard errors in parentheses

${ }^{*} p<0.10,{ }^{* *} p<0.05, * * * p<0.01$

also consistent with the research outcomes of Dhnadirek and Tang (2003), who claimed that firm performance is independent of the existence of institutional investors. Alternatively, the findings of the research contradict with opinions of some other researchers who strongly suggested the necessity of institutional ownership to enhance performance efficiency and investment due to a significant reduction of cost of agency (Shleifer and Vishny 1997; Hoque et al. 2013). This is because of the contextual difference of the studies as both were on developed country context. While examining the impact of board characteristics on the bank's 
performance, the mixed outcome is found. Almost all the characteristics of the board such as IBM, accounting experts, and board size are documented as insignificant, while only legal expert is found to play a significant role to determine banks' performance under both fixed-effect and OLS method. At a 5\% significance level, an accounting expert is found insignificant as per the random effect model. These results provide an insight that the board composition does not play much significant role in TFP. However, law experts on the board play a crucial role in the productivity of banks. The finding is well supported by Villiers et al. (2011). While investigating the relationship between control variables and TFP, the study found a positive and significant effect of bank age and ROE on TFP, while bank size and NP have no effect. As the coefficient of age is positively significant under all models, it indicates that the banks having higher experience have better productivity in the industry. Likely, the positive relationship of ROE with TFP indicates that the banks having higher profitability have better productivity. Our findings are consistent with the research findings of Mia and Ben Soltane (2016), who concluded that profitability is positively correlated with financial and operational self-sufficiency, which indirectly increased productivity.

\section{Conclusion, implications, and future research}

Noteworthy attention has been given by the researcher to explore organizational productivity and efficiency throughout the world. Surprisingly, not such an investigation has been made to analyze the impact of corporate governance on productivity. Moreover, in Bangladesh, among 30 listed banks, eight banks (presented in Appendix 2) shows unproductive and what are the reasons behind the results is still unexplored. Therefore, research aiming to explore the reason behind such limitation of the banking sector carries huge significance. Such research need shapes the aim of this research that attempts to examine the determinants of bank's productivity by giving special heed to ownership structures and board diversification. In Bangladesh, the board of directors holds the largest part of shares (33.24\%); they would like to ensure better performance of their firms as possible for selfinterest. Recently, because of their foreign market exposure, the foreigners are showing their interest in investing in the Bangladeshi stock market; their diversified knowledge and experiences make the firms more productive. As per the study of Uddin and Choudhury (2008), though the percentage of shares held by a foreigner is limited; their ownership is increasing tremendously due to the growth of multinational ventures. On the other hand, due to political consideration, some members without any banking experience are being appointed on the board of directors. Former governor of Bangladesh Bank, Dr. Shaleh Uddin Ahmed, showed his concern regarding such political appointment in the board of directors of the commercial bank (New Age 2012). ${ }^{2}$ Thus, a board with an inexperienced member might not be supportive in ensuring the productivity and efficiency of the banking institutions in Bangladesh.

\footnotetext{
$\overline{2}$ A Bangladeshi English-language daily newspaper published from Dhaka.
} 
However, the study provides researchers, academicians, management of the banks, and regulatory bodies a new insight into how the corporate governance impacts the banks' productivity. Prior studies examined only to what extent the banks are efficient or productive (García-Alcober et al. 2019), the present study tries to explore how the firms' productivity is influenced by the different capital structures, board composition, and financial performance. The study found a positive relationship of ownership structure, legal experts in the board, and financial performance with productivity. Theoretically, the study proves that different stakeholders highly instigate the firms' productivity. This study also documented that strong corporate governance provides better align executives' and shareholders' interests to improve banks' productivity.

A positive relationship of foreign and directors' ownership on productivity implies that with increasing the percentage of foreign and directors' shares in the banks, productivity also increases. As the foreign owners invest a significant contribution to the capital, they create pressure on the board to promote better performance (Ciftci et al. 2019). Similarly, as the directors are appointed to protect the interest of the shareholders, they continue their monitoring efforts to enhance the productivity of their institutions (Chen et al. 2008). Therefore, the Bangladesh Bank, as a regulatory body, should implement such a strategy that makes the banks bound to sell a certain percentage of shares to directors and foreigners. This step makes them more powerful by possessing a significant number of shares and enables them to provide an intense effort to increase productivity. However, if they hold too many shares, they may misuse their power violating corporate rules. For example, if the foreigners hold a bulk share of a firm, they may transfer money to their home country by adopting illegal ways, which makes the firm unproductive. However, bank management should include more legal experts on the board of directors; as they keep in touch whether their firms are maintaining the rules and regulations. Proper compliance of corporate rules and significant contribution to CSR results in greater stakeholders' loyalty and better financial performance. Additionally, the banks and regulatory bodies should keep the board size as short as possible, since larger board size requires higher cost, it may lessen banks' productivity. In Bangladesh, the average size of the board is 14; the regulatory authority should cut off the board size to a significant extent. Like the board size, independent directors shows an insignificant impact on productivity as most of the independent board members are appointed from the non-bankers, academician, who have no practical experience; they could not play any significant role to enhance the banks' productivity. The banks and regulatory bodies are suggested to appoint the directors who have specialized knowledge and experience, not considering the political background.

The study has several limitations. First, the study considers only listed commercial banks; it may not represent the entire Bangladeshi financial sector, it consists of both listed and non-listed banks and NBFIs as well. The second limitation is related to the global implication of the outcome of this study. Since Bangladesh is a developing country, the implication of this study might not be applicable in developed countries. Finally, though some significant board characteristics have been included in the model, some other crucial characteristics of 
corporate governance such as female ownership, family ownership, government ownership, CEO duality, political directors, female directors, and audit committee are not considered in the study. Therefore, considering the limitations of the study, future researchers may consider the whole financial sector with large sample size. Moreover, all features of corporate governance may be considered to have robust results. Additionally, future researchers could explore the influence of corporate governance on the firms' efficiency with a cross-country investigation.

Open Access This article is licensed under a Creative Commons Attribution 4.0 International License, which permits use, sharing, adaptation, distribution and reproduction in any medium or format, as long as you give appropriate credit to the original author(s) and the source, provide a link to the Creative Commons licence, and indicate if changes were made. The images or other third party material in this article are included in the article's Creative Commons licence, unless indicated otherwise in a credit line to the material. If material is not included in the article's Creative Commons licence and your intended use is not permitted by statutory regulation or exceeds the permitted use, you will need to obtain permission directly from the copyright holder. To view a copy of this licence, visit http:// creativecommons.org/licenses/by/4.0/.

\section{Appendix 1: Definition of selected variables}

\begin{tabular}{|c|c|c|}
\hline Classification & Name & Definition \\
\hline \multirow[t]{3}{*}{ Input } & $\begin{array}{l}\text { Interest expense } \\
\quad \text { (INE) }\end{array}$ & Cost for acquiring depositors' funds (Azad et al. 2017) \\
\hline & $\begin{array}{l}\text { Non-interest } \\
\text { expense } \\
\text { (NONINE) }\end{array}$ & $\begin{array}{l}\text { Non-interest expense is mainly linked with the quality of } \\
\text { management (Azad et al. 2017) }\end{array}$ \\
\hline & Deposit (D) & $\begin{array}{l}\text { The fund collected from depositors (Alhassan and Ohene- } \\
\text { Asare 2016; Nartey et al. 2019) }\end{array}$ \\
\hline \multirow[t]{3}{*}{ Output } & $\begin{array}{l}\text { Interest income } \\
\quad \text { (INI) }\end{array}$ & $\begin{array}{l}\text { Income generated using depositors' funds as a loan (Sufian } \\
\text { and Habibullah 2010) }\end{array}$ \\
\hline & $\begin{array}{l}\text { Non-interest } \\
\text { income } \\
\text { (NONINI) }\end{array}$ & $\begin{array}{l}\text { Income from fees, commissions, investment in the capital } \\
\text { market, etc. (Tanna et al. 2017) }\end{array}$ \\
\hline & Loan (L) & $\begin{array}{l}\text { The portion of the deposit that has been lent to borrower } \\
\text { (Maredza and Ikhide 2013; Murillo-Melchor et al. 2010) }\end{array}$ \\
\hline \multirow{3}{*}{$\begin{array}{l}\text { Ownership } \\
\text { structures' } \\
\text { components }\end{array}$} & Foreign share (FS) & $\begin{array}{l}\text { Foreign share is the portion of total ownership of bank } \\
\text { ownership structure }\end{array}$ \\
\hline & Director share (DS) & $\begin{array}{l}\text { Director share is a proxy for domestic ownership that } \\
\text { entitles those shareholders to monitor the performance of } \\
\text { the management of the bank (Boone and White 2015) }\end{array}$ \\
\hline & $\begin{array}{l}\text { Institutional share } \\
\quad \text { (IS) }\end{array}$ & $\begin{array}{l}\text { Institutional share is the portion of ownership of the firm } \\
\text { that is held by non-bank institutions which keep the } \\
\text { diverse impact on investment decision, information } \\
\text { production, and firm policies (Gillan and Starks 2000) }\end{array}$ \\
\hline
\end{tabular}


Appendix continued

\begin{tabular}{|c|c|c|}
\hline Classification & Name & Definition \\
\hline \multirow[t]{4}{*}{$\begin{array}{l}\text { Board } \\
\text { characteristics }\end{array}$} & $\begin{array}{l}\text { Board size } \\
\text { (BOARD) }\end{array}$ & The number of directors on the board \\
\hline & $\begin{array}{l}\text { Independent board } \\
\text { member (IBM) }\end{array}$ & $\begin{array}{l}\text { Independent board members are non-executive external } \\
\text { members having prior expertise that make them enable } \\
\text { monitoring firm's performance and reducing agency } \\
\text { conflict (Adams and Ferreira 2007; Terjesen et al. 2016) }\end{array}$ \\
\hline & $\begin{array}{l}\text { Accounting experts } \\
\text { (AE) }\end{array}$ & $\begin{array}{l}\text { Accounting experts are those on the board who play an } \\
\text { accounting watchdog role by focusing on supervision, } \\
\text { transparency and accountability of recording and } \\
\text { reporting of financial data (Kassinis and Vafeas } 2002 \text {; } \\
\text { Masud et al. 2019) }\end{array}$ \\
\hline & Legal experts (LE) & $\begin{array}{l}\text { Law experts are expert board members with a law } \\
\text { background, concentrate on legal guidance on financial } \\
\text { and nonfinancial deeds with external, resolving legal } \\
\text { issues (Masud et al. 2019) }\end{array}$ \\
\hline \multirow[t]{4}{*}{ Controlled factors } & Bank size (SIZE) & $\begin{array}{l}\text { The natural logarithm of bank assets is termed as bank size } \\
\text { that ensures prospective scale economies (Laeven et al. } \\
\text { 2016) }\end{array}$ \\
\hline & $\begin{array}{l}\text { Age of Banks } \\
\text { (AGE) }\end{array}$ & $\begin{array}{l}\text { The natural logarithm of bank age dictates the number of } \\
\text { operational years that is positively related to economies } \\
\text { of scale since the lender could understand the clients in a } \\
\text { better way (Rashid and Twaha 2013) }\end{array}$ \\
\hline & Net Profit (NP) & $\begin{array}{l}\text { Natural logarithm of bank net profit is a measurement of } \\
\text { bank profitability that is produced by adjusting operating } \\
\text { profit by considering tax provision, loan and loss } \\
\text { provision, loan and loss reserve, reserve for general risks } \\
\text { (Fiordelisi and Molyneux 2010) }\end{array}$ \\
\hline & $\begin{array}{l}\text { Return on Equity } \\
\quad(\mathrm{ROE})\end{array}$ & $\begin{array}{l}\text { ROE is considered as one of the best proxies for } \\
\text { measurement of the overall performance of the bank } \\
\text { (Beck et al. 2008; Ho and Wu 2006) }\end{array}$ \\
\hline
\end{tabular}

\section{Appendix 2: Average total factor productivity (TFP) of 30 listed banks (2013-2017)}

\begin{tabular}{lllllll}
\hline Id & Name of the banks & $2013-2014$ & $2014-2015$ & $2015-2016$ & $2016-2017$ & Average \\
\hline 1 & Al-Arafa Islami Bank Ltd. & 1.003 & 0.998 & 1.005 & 2.36 & 1.342 \\
2 & Dutch Bangla Bank Ltd. & 1.052 & 1.136 & 1.132 & 1.221 & 1.135 \\
3 & Islami Bank Bangladesh Ltd. & 1.084 & 1.163 & 1.075 & 1.047 & 1.092 \\
4 & Pubali Bank Ltd. & 0.997 & 1.059 & 1.104 & 1.077 & 1.059 \\
5 & Trust Bank Ltd. & 1.117 & 1.014 & 0.966 & 1.135 & 1.058 \\
6 & IFIC Bank Ltd. & 1.036 & 1.075 & 1.028 & 1.047 & 1.047 \\
7 & BRAC Bank Ltd. & 0.986 & 1.056 & 1.126 & 1.002 & 1.043 \\
8 & Prime Bank Ltd. & 0.904 & 1.012 & 1.088 & 1.165 & 1.042 \\
\hline
\end{tabular}


Appendix continued

\begin{tabular}{lllllll}
\hline Id & Name of the banks & $2013-2014$ & $2014-2015$ & $2015-2016$ & $2016-2017$ & Average \\
\hline 9 & Bank Asia Ltd. & 1.01 & 0.978 & 1.058 & 1.118 & 1.041 \\
10 & National Bank Ltd. & 1.087 & 1.011 & 1.016 & 1.05 & 1.041 \\
11 & Mutual Trust Bank Ltd. & 1.068 & 0.999 & 1.01 & 1.071 & 1.037 \\
12 & Premier Bank Ltd. & 0.981 & 1.007 & 1.046 & 1.089 & 1.031 \\
13 & The City Bank Ltd. & 1.049 & 1.002 & 0.967 & 1.102 & 1.03 \\
14 & Rupali Bank Ltd. & 1.261 & 1.023 & 0.764 & 1.069 & 1.029 \\
15 & United Commercial Bank Ltd. & 1.082 & 1.025 & 0.966 & 1.04 & 1.028 \\
16 & Uttara Bank Ltd. & 1.098 & 0.996 & 0.955 & 1.058 & 1.027 \\
17 & Marcentile Bank Ltd. & 1.012 & 0.963 & 1.095 & 1.026 & 1.024 \\
18 & AB Bank Ltd. & 1.023 & 1.075 & 0.905 & 1.088 & 1.023 \\
19 & Jamuna Bank Ltd. & 0.948 & 0.991 & 1.086 & 1.049 & 1.019 \\
20 & Eastern Bank Ltd. & 1.036 & 0.995 & 1.02 & 1.013 & 1.016 \\
21 & ICB Islamic Bank Ltd. & 1.058 & 1.055 & 1.019 & 0.911 & 1.011 \\
22 & One Bank Ltd. & 1.028 & 0.919 & 1.006 & 1.069 & 1.006 \\
23 & Shahjalal Islami Bank Ltd. & 0.874 & 0.955 & 1.074 & 1.089 & 0.998 \\
24 & Social Islami Bank Ltd. & 0.95 & 1.056 & 0.982 & 0.999 & 0.997 \\
25 & Dhaka Bank Ltd. & 0.907 & 0.957 & 1.004 & 1.073 & 0.985 \\
26 & Southeast Bank Ltd. & 0.917 & 0.995 & 0.957 & 1.049 & 0.98 \\
27 & NCC Bank Ltd. & 0.939 & 0.991 & 1.011 & 0.963 & 0.976 \\
28 & First Security Islami Bank Ltd. & 0.978 & 0.933 & 0.983 & 0.986 & 0.97 \\
29 & Standard Bank Ltd. & 0.956 & 0.892 & 0.933 & 1.095 & 0.969 \\
30 & Exim Bank Ltd. & 0.988 & 0.979 & 0.917 & 0.983 & 0.967 \\
& Average & 1.014 & 1.01 & 1.01 & 1.101 & 1.034 \\
\hline
\end{tabular}

\section{References}

Adams, R.B., and D. Ferreira. 2007. A theory of friendly boards. The Journal of Finance 62 (1): 217-250.

Adams, R.B., and H. Mehran. 2012. Bank board structure and performance: Evidence for large bank holding companies. Journal of Financial Intermediation 21 (2): 243-267.

Al-ahdal, W.M., M. Alsamhi, M.I. Tabash, and N.H. Farhan. 2020. The impact of corporate governance on financial performance of Indian and GCC listed firms: An empirical investigation. Research in International Business and Finance. https://doi.org/10.1016/j.ribaf.2019.101083.

Alexakis, C., M. Izzeldin, J. Johnes, and V. Pappas. 2019. Performance and productivity in Islamic and conventional banks: Evidence from the global financial crisis. Economic Modelling 79: 1-14.

Alhassan, A.L., and K. Ohene-Asare. 2016. Competition and bank efficiency in emerging markets: Empirical evidence from Ghana. African Journal of Economic and Management Studies 7 (2): $268-288$.

Arif, A., and A. Nauman Anees. 2012. Liquidity risk and performance of banking system. Journal of Financial Regulation and Compliance 20 (2): 182-195.

Athanasoglou, P., Delis, M., and Staikouras, C. 2006. Determinants of bank profitability in the South Eastern European region. MPRA Paper No. 10274, Posted 20 Sep 2008 04:31 UTC. https://mpra.ub. uni-muenchen.de/10274/

Azad, M.A.K., S. Munisamy, A.K.M. Masum, P. Saona, and P. Wanke. 2017. Bank efficiency in Malaysia: A use of malmquist meta-frontier analysis. Eurasian Business Review 7 (2): 287-311. 
Banker, R., R. Natarajan, and D. Zhang. 2019. Two-stage estimation of the impact of contextual variables in stochastic frontier production function models using data envelopment analysis: Second stage OLS versus bootstrap approaches. European Journal of Operational Research 278 (2): 368-384.

Banker, R.D., and R. Natarajan. 2008. Evaluating contextual variables affecting productivity using data envelopment analysis. Operations Research 56 (1): 48-58.

Banna, H., R. Ahmad, and E.H. Koh. 2017. Determinants of commercial banks' efficiency in Bangladesh: Does crisis matter? The Journal of Asian Finance. Economics and Business (JAFEB) 4 (3): 19-26.

Basharat, B., M. Hudon, and A. Nawaz. 2015. Does efficiency lead to lower prices? A new perspective from microfinance interest rates. Strategic Change 24 (1): 49-66.

Bassem, B.S. 2014. Total factor productivity change of MENA microfinance institutions: A Malmquist productivity index approach. Economic Modelling 39: 182-189.

Beck, T., A. Demirguc-Kunt, L. Laeven, and R. Levine. 2008. Finance, firm size, and growth. Journal of Money, Credit and Banking 40 (7): 1379-1405.

Boone, A.L., and J.T. White. 2015. The effect of institutional ownership on firm transparency and information production. Journal of Financial Economics 117 (3): 508-533.

Brewster, C., G. Wood, and M. Brookes. 2008. Similarity, isomorphism or duality? Recent survey evidence on the human resource management policies of multinational corporations. British Journal of Management 19 (4): 320-342.

Chandran, V., and V. Pandiyan. 2008. Technical efficiency and technological change in Malaysian service industries. Applied Economics Letters 15 (8): 655-657.

Chen, Q., I. Goldstein, and W. Jiang. 2008. Directors' ownership in the US mutual fund industry. The Journal of Finance 63 (6): 2629-2677.

Ciftci, I., E. Tatoglu, G. Wood, M. Demirbag, and S. Zaim. 2019. Corporate governance and firm performance in emerging markets: Evidence from Turkey. International Business Review 28 (1): 90-103.

Cooper, W. W., Seiford, L. M., and Zhu, J. 2011. Data envelopment analysis: History, models, and interpretations. In Handbook on data envelopment analysis 1-39. Springer, Boston, MA. https://doi. org/10.1007/978-1-4419-6151-8_1.

Cullen, M., Kirwan, C., and Brennan, N. 2006. Comparative analysis of corporate governance theory: The agency-stewardship continuum. Paper presented at the 20th annual conference of the Irish Accounting \& Finance Association, Institute of Technology, Tralee.

Dalton, C.M., and D.R. Dalton. 2005. Boards of directors: Utilizing empirical evidence in developing practical prescriptions. British Journal of Management 16: S91-S97.

Daskovska, A., L. Simar, and S. Van Bellegem. 2010. Forecasting the Malmquist productivity index. Journal of Productivity Analysis 33 (2): 97-107.

De Bandt, O., and E.P. Davis. 2000. Competition, contestability and market structure in European banking sectors on the eve of EMU. Journal of Banking \& Finance 24 (6): 1045-1066.

De Villiers, C., V. Naiker, and C.J. Van Staden. 2011. The effect of board characteristics on firm environmental performance. Journal of Management 37 (6): 1636-1663.

Dhnadirek, R., and J. Tang. 2003. Corporate governance problems in Thailand: Is ownership concentration the cause? Asia Pacific Business Review 10 (2): 121-138.

Diamond, D.W., and R.G. Rajan. 2005. Liquidity shortages and banking crises. The Journal of finance 60 (2): 615-647.

Emrouznejad, A., and Cabanda, E. 2014. Introduction to data envelopment analysis and its applications. In Handbook of research on strategic performance management and measurement using data envelopment analysis, 235-255. IGI Global.

Epure, M., K. Kerstens, and D. Prior. 2011. Bank productivity and performance groups: A decomposition approach based upon the Luenberger productivity indicator. European Journal of Operational Research 211 (3): 630-641.

Färe, R., S. Grosskopf, M. Norris, and Z. Zhang. 1994. Productivity growth, technical progress, and efficiency change in industrialized countries. The American economic review 84: 66-83.

Farrar, D.E., and R.R. Glauber. 1967. Multicollinearity in regression analysis: the problem revisited. The Review of Economic and Statistics 49 (1): 92-107.

Ferrier, G. 2001. Bank efficiency and economic growth: The case of ASEAN. Arkansas: Department of Economics, University of Arkansas.

Fiordelisi, F., D. Marques-Ibanez, and P. Molyneux. 2011. Efficiency and risk in European banking. Journal of Banking \& Finance 35 (5): 1315-1326. 
Fiordelisi, F., and P. Molyneux. 2010. The determinants of shareholder value in European banking. Journal of Banking \& Finance 34 (6): 1189-1200.

Fu, X.M., Y.R. Lin, and P. Molyneux. 2014. Bank efficiency and shareholder value in Asia Pacific. Journal of International Financial Markets, Institutions and Money 33: 200-222.

García-Alcober, M.P., D. Prior, E. Tortosa-Ausina, and M. Illueca. 2019. Risk-taking behavior, Earnings quality, and bank performance: A profit frontier approach. BRQ Business Research Quarterly. https://doi.org/10.1016/j.brq.2019.02.003.

Gillan, S.L., and L.T. Starks. 2000. Corporate governance proposals and shareholder activism: The role of institutional investors. Journal of Financial Economics 57 (2): 275-305.

Girardone, C., P. Molyneux, and E.P. Gardener. 2004. Analysing the determinants of bank efficiency: The case of Italian banks. Applied Economics 36 (3): 215-227.

Grifell-Tatje, E., and C.K. Lovell. 1996. Deregulation and productivity decline: The case of Spanish savings banks. European Economic Review 40 (6): 1281-1303.

Haniffa, R., and M. Hudaib. 2006. Corporate governance structure and performance of Malaysian listed companies. Journal of Business Finance \& Accounting 33 (7-8): 1034-1062.

Hair, J.F., R.E. Anderson, R.L. Tatham, and W.C. Black. 1984. Multivariate data analysis with readings, 1995. Tulsa, OK: Petroleum Publishing.

Henriques, I.C., V.A. Sobreiro, H. Kimura, and E.B. Mariano. 2018. Efficiency in the Brazilian banking system using data envelopment analysis. Future Business Journal 4 (2): 157-178.

Hill, C.W., and T.M. Jones. 1992. Stakeholder-agency theory. Journal of Management Studies 29 (2): 131-154.

Ho, C.-T., and Y.-S. Wu. 2006. Benchmarking performance indicators for banks. Benchmarking 13 (1/2): 147-159.

Ho, C.K. 2005. Corporate governance and corporate competitiveness: An international analysis. Corporate Governance: An International Review 13 (2): 211-253.

Honohan, P., and D. Klingebiel. 2003. The fiscal cost implications of an accommodating approach to banking crises. Journal of Banking \& Finance 27 (8): 1539-1560.

Hoque, M.R., and M.I. Rayhan. 2013. Efficiency measurement on banking sector in Bangladesh. Dhaka University Journal of Science 61 (1): 1-5.

Hoque, M.Z., Islam, R.M., and Ahmed, H. 2013. Corporate governance and bank performance: The case of Bangladesh. SSRN 2208903.

Jensen, M.C., and W.H. Meckling. 1976. Theory of the firm: Managerial behavior, agency costs and ownership structure. Journal of Financial Economics 3 (4): 305-360.

Kassinis, G., and N. Vafeas. 2002. Corporate boards and outside stakeholders as determinants of environmental litigation. Strategic Management Journal 23 (5): 399-415.

Klein, A. 2002. Audit committee, board of director characteristics, and earnings management. Journal of Accounting and Economics 33 (3): 375-400.

Kusnadi, Y., K.S. Leong, T. Suwardy, and J. Wang. 2016. Audit committees and financial reporting quality in Singapore. Journal of Business Ethics 139 (1): 197-214.

Laeven, L., L. Ratnovski, and H. Tong. 2016. Bank size, capital, and systemic risk: Some international evidence. Journal of Banking \& Finance 69: S25-S34.

Liu, W., H. Yang, and G. Zhang. 2012. Does family business excel in firm performance? An institutionbased view. Asia Pacific Journal of Management 29 (4): 965-987.

Malmquist, S. 1953. Index numbers and indifference surfaces. Trabajos de Estadistica y de Investigacion Operativa 4 (2): 209-242.

Maredza, A., and S. Ikhide. 2013. Measuring the impact of the global financial crisis on efficiency and productivity of the banking system in South Africa. Mediterranean Journal of Social Sciences 4 (6): 553.

Masud, M., A. Kaium, S.M. Bae, J. Manzanares, and J.D. Kim. 2019. Board directors' expertise and corporate corruption disclosure: The moderating role of political connections. Sustainability 11 (16): 4491.

Matthews, K., and N.X. Zhang. 2010. Bank productivity in China 1997-2007: Measurement and convergence. China Economic Review 21 (4): 617-628.

McDonald, J. 2009. Using least squares and tobit in second stage DEA efficiency analyses. European Journal of Operational Research 197 (2): 792-798.

Mia, M.A., and B.I.B. Soltane. 2016. Productivity and its determinants in microfinance institutions (MFIs): Evidence from South Asian countries. Economic Analysis and Policy 51: 32-45. 
Mirzaei, A., T. Moore, and G. Liu. 2013. Does market structure matter on banks' profitability and stability? Emerging vs advanced economies. Journal of Banking \& Finance 37 (8): 2920-2937.

Murillo-Melchor, C., J.M. Pastor, and E. Tortosa-Ausina. 2010. A bootstrap approach to analyse productivity growth in European banking. Journal of the Operational Research Society 61 (12): 1729-1745.

Nartey, S.B., K.A. Osei, and E. Sarpong-Kumankoma. 2019. Bank productivity in Africa. International Journal of Productivity and Performance Management. https://doi.org/10.1108/IJPPM-09-20180328.

Parinduri, R.A., and Y.E. Riyanto. 2014. Bank ownership and efficiency in the aftermath of financial crises: Evidence from I ndonesia. Review of Development Economics 18 (1): 93-106.

Pervez, M., M.H.U. Rashid, M.A.I. Chowdhury, and M. Rahaman. 2018. Predicting the Stock market efficiency in weak form: A study on Dhaka Stock Exchange. International Journal of Economics and Financial Issues 8 (5): 88.

Preffer, J., and G. Salancik. 1978. The external control of organizations: A resource dependence perspective. The external control of organizations: a resource dependence perspective. New York: Harper \& Row.

Rashid, A., and K. Twaha. 2013. Exploring the determinants of the productivity of Indian microfinance institutions. Theoretical and Applied Economics 18 (12): 83-96.

Reaz, M., and T. Arun. 2006. Corporate governance in developing economies: perspective from the banking sector in Bangladesh. Journal of Banking Regulation 7 (1-2): 94-105.

Romano, G., Ferretti, P., and Quirici, M.C. 2012. Corporate Governance and efficiency of Italian Bank Holding companies during the financial crisis: an empirical analysis, 102-133.

Romano, G., Ferretti, P., and Rigolini, A. 2012. Corporate governance and performance in Italian banking groups. Paper to be presented at the International conference.

Shehzad, C.T., and J. De Haan. 2015. Supervisory powers and bank risk taking. Journal of International Financial Markets, Institutions and Money 39: 15-24.

Shleifer, A., and R.W. Vishny. 1997. A survey of corporate governance. The Journal of Finance 52 (2): 737-783.

Simar, L., and P.W. Wilson. 2011. Two-stage DEA: Caveat emptor. Journal of Productivity Analysis 36 (2): 205 .

Sufian, F. 2011. Banks total factor productivity change in a developing economy: Does ownership and origins matter? Journal of Asian Economics 22 (1): 84-98.

Sufian, F., and M.S. Habibullah. 2010. Bank-specific, industry-specific and macroeconomic determinants of bank efficiency: Empirical evidence from the Thai banking sector. Margin: The Journal of Applied Economic Research 4 (4): 427-461.

Sufian, F., and F. Kamarudin. 2013. Efficiency of the Bangladesh Banking Sector: Evidence from the profit function. Jindal Journal of Business Research 2 (1): 43-57.

Sufian, F., and M. Shah Habibullah. 2010. Developments in the efficiency of the Thailand banking sector: A DEA approach. International Journal of Development Issues 9 (3): 226-245.

Tamatam, R., P. Dutta, G. Dutta, and S. Lessmann. 2019. Efficiency analysis of Indian banking industry over the period 2008-2017 using data envelopment analysis. Benchmarking: An International Journal. 26: 2417-2442.

Tanna, S., Y. Luo, and G. De Vita. 2017. What is the net effect of financial liberalization on bank productivity? A decomposition analysis of bank total factor productivity growth. Journal of Financial Stability 30: 67-78.

Terjesen, S., E.B. Couto, and P.M. Francisco. 2016. Does the presence of independent and female directors impact firm performance? A multi-country study of board diversity. Journal of Management \& Governance 20 (3): 447-483.

Uddin, S., and J. Choudhury. 2008. Rationality, traditionalism and the state of corporate governance mechanisms: Illustrations from a less-developed country. Accounting, Auditing \& Accountability Journal 21 (7): 1026-1051.

Wijesiri, M., and M. Meoli. 2015. Productivity change of microfinance institutions in Kenya: A bootstrap Malmquist approach. Journal of Retailing and Consumer Services 25: 115-121.

Publisher's Note Springer Nature remains neutral with regard to jurisdictional claims in published maps and institutional affiliations. 